\title{
Postharvest Height Suppression of Potted Tulips with Paclobutrazol
}

\author{
Gary L. McDaniel \\ Department of Ornamental Horticulture and Landscape Design, \\ University of Tennessee, Knoxville, TN 37901-1071
}

Additional index words. Tulipa gesneriana, plant growth retardants, ancymidol

Abstract. Suppression of scape elongation by paclobutrazol and ancymidol of potted 'Paul Richter' tulips (Tulipa gesneriana, L.) under greenhouse and low light postharvest environments were compared. Soil" drench applications of paclobutrazol at 0.25 or 0.50 $\mathrm{mg} / 15-\mathrm{cm}$ pot were as effective as ancymidol at 0.50 or $0.75 \mathrm{mg} / \mathrm{pot}$ in limiting scape lengths at colored bud stage and at senescence. Paclobutrazol pre-plant bulb soaks at 2.5 or 5.0 mg-liter ${ }^{-1}$ prevented excessive scape elongation during low light exposure, whereas ancymidol bulb soaks were ineffective. Neither plant growth regulator reduced flower size or affected petal color. Paclobutrazol applied as a soil drench or as a bulb soak increased days required up colored bud stage up to 4 days, whereas neither chemical affected post-greenhouse, life of tulips. Chemical names used: $\left(R^{*}, R^{*}\right)-( \pm)$ $\beta$-[(4-chlorophenyl) methyl]- $\alpha$-(1,1 -dimethyl)-1H-1,2,4-triazol-1-ethanol (paclobutrazol) and $\alpha$-cyclopropyl- $\alpha$ - (4-methoxyphenyl)-5-pyrimidinemethanol (ancymidol).

Tulips are an ideal winter crop because they require cool greenhouse temperatures for optimal flower development. However, well-grown potted tulips that are of suitable market height in the greenhouse often become excessively tall when placed in retail shops and home interiors. This is a response to reduced light levels and warmer temperatures. These elongated tulips possess weaker scapes and often lose their upright form.

Excessive tulip height may be prevented by either shortening the length of low-temperature programming or by applying growthretarding chemicals (De Hertogh, 1974). Manipulation of the cooling period is undesirable since improper temperature regulation is a major cause of flower abortion in tulips (Gilford and Rees, 1974). Ancymidol has clearance from the Environmental Protection Agency for tulips and is applied at the beginning of stem elongation (Sachs and Hackett, 1972; Shoub and De Hertogh, 1974). Previous research (unpublished data) has shown that ancymidol soil drenches at rates as low as $0.2 \mathrm{mg} / 15-\mathrm{cm}$ pot (1.6 liters) applied 3 to 5 days following removal from the rooting room were as effective in limiting tulip height as were two foliar spray applications of $200 \mathrm{mg} \cdot$ liter $^{-1}$ applied 1 week apart. Paclobutrazol soil drenches were shown to reduce scape elongation of mid- and lateseason potted tulips (Menhenett and Hanks, 1983). However, higher concentrations of paclobutrazol than ancymidol were required to achieve a similar reduction of post-flowering scape lengths. Differences in tulip cultivar responses to these chemicals were also reported.

Preplant bulb-dip chemical treatment allows application at an earlier developmental

Received for publication 14 Apr. 1989. The cost of publishing this paper was defrayed in part by the payment of page charges. Under postal regulations, this paper therefore must be hereby marked advertisement solely to indicate this fact. stage than with soil drenches or sprays. Ancymidol bulb-dip treatments $\left(264 \mathrm{mg} \cdot\right.$ liter $^{-1}$ for 2 see) were more effective than soil drenches on Easter lilies (Lewis and Lewis, 1980) and 'Mid-Century' hybrid lilies (Simmonds and Cummings, 1977). Tulip height, however, was not limited by 12 -hr soaks in ancymidol at 2 to $10 \mathrm{mg} \cdot$ liter $^{-1}$ (Kincaid and McDaniel, 1979).

Paclobutrazol is a pyrimidine derivative that has shown growth-controlling activity on a wide range of plants (Freeborg and Daniel, 1981; McDaniel, 1983; McDaniel, 1986; Shanks, 1980; Sterrett, 1985). It is not
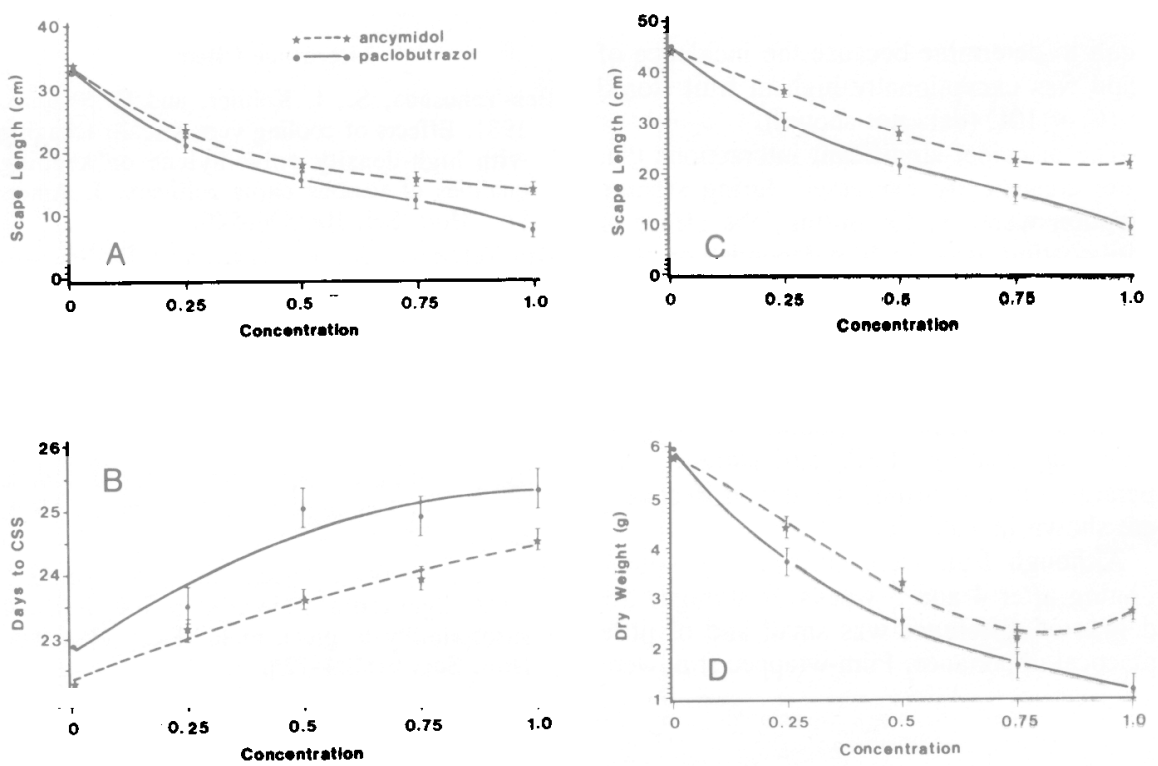

Fig. 1. Effects of paclobutrazol and ancymidol soil drenches on potted tulips under greenhouse conditions and following placement in a low-light holding environment. (A) Scape lengths at CSS. $\hat{\mathrm{Y}}$ $=34.1-55.6 \mathrm{X}+58.6 \mathrm{X}^{2}-23.3 \mathrm{X}^{3}$ (ancymidol), $\hat{\mathrm{Y}}=33.8-66.7 \mathrm{X}+80.6 \mathrm{X}^{2}-40.5 \mathrm{X}^{3}$ (paclobutrazol), $R^{2}=0.9863$. (B) Days required to reach CSS. $\hat{Y}=22.3+4.8 \mathrm{X}-6.3 \mathrm{X}^{2}+$ $3.7 \mathrm{X}^{3}$ (ancymidol), $\hat{\mathrm{Y}}=22.8+3.7 \mathrm{X}+0.8 \mathrm{X}^{2}-2.1 \mathrm{X}^{3}$ (paclobutrazol), $R^{2}=0.8826$. (C) Scape lengths at senescence. $\hat{Y}=44.9-33.4 X-13.4 X^{2}+23.8 X^{3}$ (ancymidol), $\hat{Y}=45.6=80.1 X$ $+84.4 \mathrm{X}^{2}-41.1 \mathrm{X}^{3}$ (paclobutrazol), $R^{2}=0.9830$. (D) Scape dry weights at senescence. $\hat{Y}=5.8$ - 4.5X - 5.1 $\mathrm{X}^{2}+6.4 \mathrm{X}^{3}$ (ancymidol), $\hat{\mathrm{Y}}=6.0-11.2 \mathrm{X}+9.9 \mathrm{X}^{2}-3.6 \mathrm{X}^{3}$ (paclobutrazol), $R^{2}=0.9842$. Bars represent $\pm \mathrm{SE}$ of the means for each chemical comparison. 

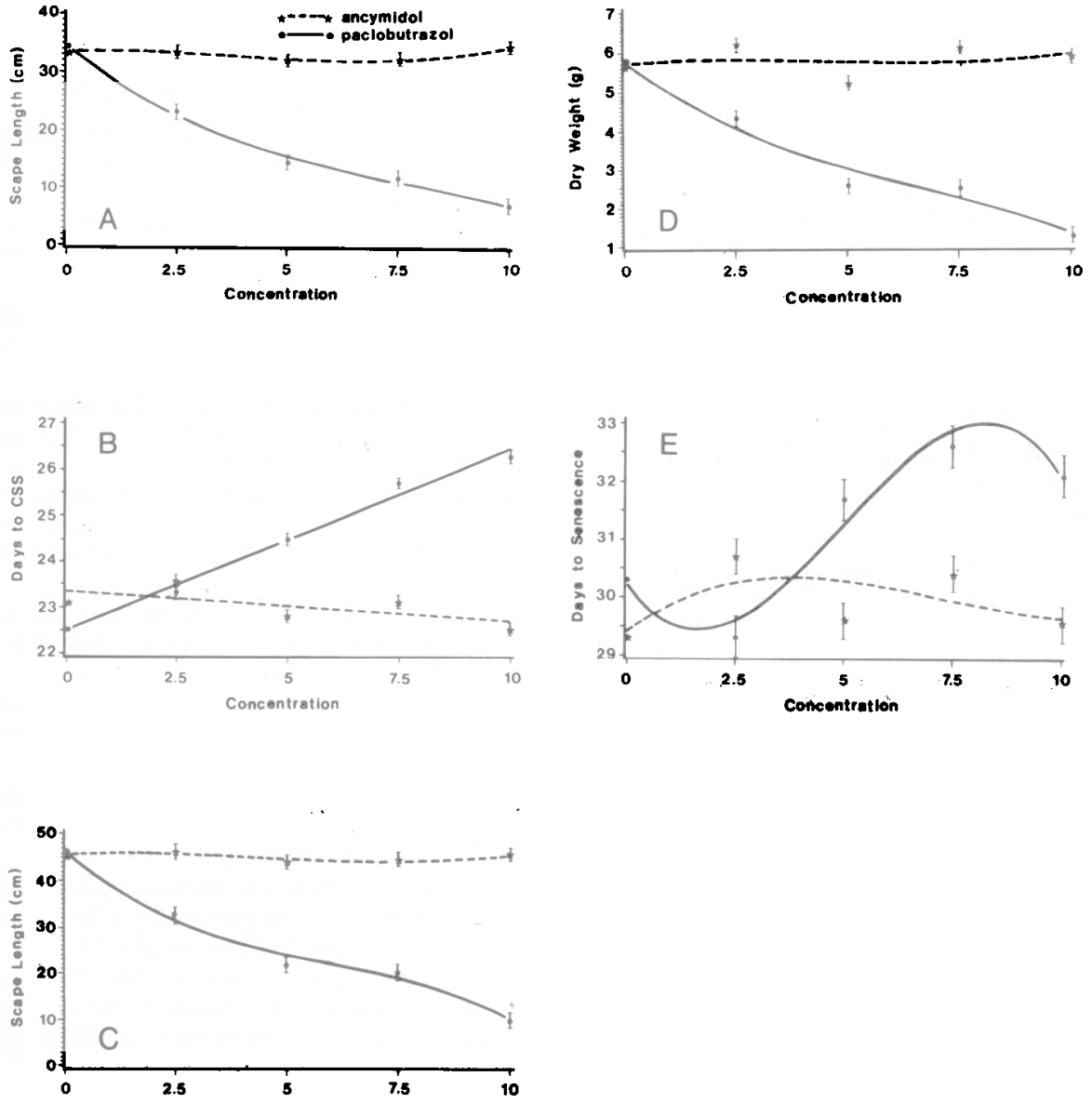

Fig. 2. Comparison of paclobutrazol and ancymidol bulb-soaks on potted tulips under greenhouse conditions and following placement in a low-light holding environment. (A) Scape lengths at CSS $\hat{\mathrm{Y}}=33.6+0.3 \mathrm{X}-0.2 \mathrm{X}^{2}+0.02 \mathrm{X}^{3}$ (ancymidol), $\hat{\mathrm{Y}}=34.5-6.2 \mathrm{X}+0.6 \mathrm{X}^{2}-0.03 \mathrm{X}^{3}$ (paclobutrazol), $R^{2}=0.9369$. (B) Days required to reach CSS. $\hat{Y}=23.32-0.06 X$ (ancymidol), $\hat{Y}=22.47+0.39 X$ (paclobutrazol), $R^{2}=0.9257$. (C) Scape lengths at senescence. $\hat{Y}=45.70$ $+0.42 \mathrm{X}-0.20 \mathrm{X}^{2}+0.02 \mathrm{X}^{3}$ (ancymidol), $\hat{\mathrm{Y}}=46.1-8.29 \mathrm{X}+1.05 \mathrm{X}^{2}-0.06 \mathrm{X}^{3}$ (paclobutrazol), $R^{2}=0.9575$. (D) Scape dry weights at senescence. $\hat{Y}=5.71+0.10 \mathrm{X}-0.03 \mathrm{X}^{2}+$ $0.002 \mathrm{X}^{3}$ (ancymidol), $\hat{\mathrm{Y}}=5.76-0.89 \mathrm{X}+0.09 \mathrm{X}^{2}-0.004 \mathrm{X}^{3}$ (paclobutrazol), $R^{2}=0.9244$. (E) Total days before seneseence. $\hat{Y}=29.41+0.55 X-0.10 \mathrm{X}^{2}+0.005 \mathrm{X}^{3}$ (ancymidol), $\hat{\mathrm{Y}}=$ $30.23-1.04 \mathrm{X}+0.38 \mathrm{X}^{2}-0.026 \mathrm{X}^{3}$ (paclobutrazol), $R^{2}=0.8635$. Bars represent $\pm \mathrm{SE}$ of the means for each chemical comparison.

Table 1. Significance level of polynomial contrasts for growth retardant soil drenches on tulips under greenhouse conditions and after being placed in a low light environment.

\begin{tabular}{|c|c|c|c|c|c|}
\hline \multirow[b]{2}{*}{ Component } & \multicolumn{2}{|c|}{ Greenhouse } & \multicolumn{3}{|c|}{ Low light } \\
\hline & $\begin{array}{l}\text { Scape } \\
\text { length } \\
(\mathrm{cm})\end{array}$ & $\begin{array}{l}\text { Days to } \\
\text { CSS }\end{array}$ & $\begin{array}{l}\text { Scape } \\
\text { length } \\
(\mathrm{cm})\end{array}$ & $\begin{array}{r}\text { Dry } \\
\text { wt } \\
(\mathrm{gm})\end{array}$ & $\begin{array}{c}\text { Days to } \\
\text { senescence }\end{array}$ \\
\hline Chemical & 0.0001 & 0.0001 & 0.0001 & 0.0001 & 0.0026 \\
\hline Rate $^{y}$ & & & & & \\
\hline Linear & 0.0001 & 0.0001 & 0.0001 & 0.0001 & 0.0007 \\
\hline Quadratic & 0.0001 & 0.0377 & 0.0001 & 0.0001 & NS \\
\hline Cubic & 0.0001 & 0.0074 & 0.0352 & 0.0103 & NS \\
\hline Chemical $\times$ rate & & & & & \\
\hline Linear & 0.0001 & 0.0001 & 0.0001 & 0.0001 & NS \\
\hline Quadratic & 0.0055 & & & & NS \\
\hline Cubic & 0.0017 & 0.0034 & 0.0001 & 0.0001 & NS \\
\hline
\end{tabular}

${ }^{2}$ Contrast data were computed to determine the effects of ancymidol and paclobutrazol; the linear, quadratic, and cubic effects of rate; and the chemical $\mathbf{x}$ rate interactions. F values $>0.05$ were considered nonsignificant (NS).

'Soil drench rates were control, $0.25,0.5,0.75$, and $1.0 \mathrm{mg} /$ pot.

Group II bulbs were detunicated, potted, and programmed as described for Group I. On 13 Feb. 1987, soil drench applications were made with either ancymidol or paclo- butrazol at $0.25,0.50,0.75$, or $1.0 \mathrm{mg} / \mathrm{pot}$ in $200 \mathrm{ml} /$ pot aliquots. A similar group of pots were drenched with water for comparison. Mean shoot length of the bulbs at the time of application was $5.5 \mathrm{~cm}$. All irrigation and fertilization for both groups were applied on demand using an injector delivering $250 \mathrm{mg} \mathrm{N} /$ liter soluble fertilizer $(15 \mathrm{~N}-$ 7P-14K).

Growth data were recorded at two stages of plant development: colored bud stage and flower senescence. Colored bud stage is normally considered the commercial shipping stage (CSS) of tulips. Scape lengths at CSS were determined as the mean distance from the nose of the bulb to the base of the flower for the five plants in each pot. Days to CSS were recorded from the beginning of forcing in the greenhouse. When each pot of tulips reached CSS, it was moved to a low light interior environment to simulate a retail sales or home condition. Tulips were exposed to $22.8 \pm 1 \mathrm{C}$ and a light level of $50 \mu \mathrm{mol} \cdot \mathrm{s}^{-1} \cdot \mathrm{m}^{-2}$ for $8 \mathrm{hr}$ daily from cool-white fluorescent lights.

Scape length measurements were again recorded as tulips reached senescence. Senescence was determined for each pot of tulips when more than two flowers per pot had petals reflexed at an angle $>120^{\circ}$ or when petals began to darken. Total days from the beginning of greenhouse forcing to senescence were determined. Plants were then harvested by cutting each scape at the nose of the bulb and discarding leaves and flowers. Scapes were placed in a forced-air oven at $70 \mathrm{C}$ for $72 \mathrm{hr}$ for dry-weight determinations. Dry weights were recorded as the mean weight of the five scapes per pot within treatments.

Treatments were arranged in a RCB design and analysis of variance was computed for each growth parameter. Cubic orthogonal comparisons were computed and regression curves plotted for significant interactions.

Soil drenches. Regression equations for soil drench concentrations vs. scape lengths at CSS, days to CSS, scape lengths at senescence, and scape dry weights at senescence are shown in Fig. 1. Polynomial contrast values indicated that chemical comparisons for scape lengths at CSS and at senescence and scape dry weights at senescence were 'highly significant (Table 1). The chemical comparison for total days to senescence was not significant and is not shown. Desirable potted tulip heights at senescence of 31 to $40 \mathrm{~cm}$ (scape lengths of 16 to $25 \mathrm{~cm}$ ) were achieved with ancymidol at 0.75 or $1.0 \mathrm{mg} /$ pot and paclobutrazol at $0.5 \mathrm{mg} /$ pot.

Increasing concentrations of paclobutrazol from 0.25 to $1.0 \mathrm{mg} /$ pot caused a greater reduction in scape lengths than did anycymidol at these drench rates (Fig. 1A). These results are in contrast to those of Menhenett and Hanks (1983), who showed soil drenches of ancymidol to be more effective than paclobutrazol at reducing tulip scape lengths. Days to CSS (Fig. 1B) were greatest for paclobutrazol treatments, but the higher rates of both chemicals caused the greatest delays in flowering. Scape length extension under low light conditions was limited to a greater degree by paclobutrazol than by ancymidol, although both chemicals effectively prevented excessive elongation (Fig. 1C), Scape dry weights were reduced along with scape lengths 
Table 2. Significance level of polynomial contrasts for growth retardant bulb soaks on tulips under greenhouse conditions and after being placed in a low light environment. ${ }^{2}$

\begin{tabular}{|c|c|c|c|c|c|}
\hline \multirow[b]{2}{*}{ Component } & \multicolumn{2}{|c|}{ Greenhouse } & \multicolumn{3}{|c|}{ Low light } \\
\hline & $\begin{array}{c}\text { Scape } \\
\text { length } \\
(\mathrm{cm})\end{array}$ & $\begin{array}{c}\text { Days to } \\
\text { CSS }\end{array}$ & $\begin{array}{c}\text { Scape } \\
\text { length } \\
\text { (cm) }\end{array}$ & $\begin{array}{r}\text { Dry } \\
\text { wt } \\
(\mathrm{gm}) \\
\end{array}$ & $\begin{array}{c}\text { Days to } \\
\text { senescence }\end{array}$ \\
\hline Chemical & 0.0001 & 0.0001 & 0.0001 & 0.0001 & 0.0001 \\
\hline \multicolumn{6}{|l|}{ Rate $^{y}$} \\
\hline Linear & 0.0001 & 0.0001 & 0.0001 & 0.0001 & 0.0001 \\
\hline Quadratic & 0.0001 & NS & 0.0001 & 0.0001 & NS \\
\hline Cubic & NS & NS & 0.0048 & NS & 0.0077 \\
\hline \multicolumn{6}{|c|}{ Chemical $\times$ rate } \\
\hline Linear & 0.0001 & 0.0001 & 0.0001 & 0.0001 & 0.0001 \\
\hline Quadratic & 0.0001 & NS & 0.0001 & 0.0001 & NS \\
\hline Cubic & 0.0001 & NS & 0.0001 & 0.0015 & 0.0002 \\
\hline
\end{tabular}

${ }^{2}$ Contrast data were computed to determine the effects of ancymidol and paclobutrazol; the linear, quadratic, and cubic effects of rate; and the chemical $\times$ rate interactions. $F$ values $>0.05$ were considered nonsignificant (NS)

Bulb-soak rates were control, 2.5, 5, 7.5, and $10 \mathrm{mg} \cdot \mathrm{liter}{ }^{-1}$ for $1 \mathrm{hr}$.

by both chemicals (Fig. 1D). Paclobutrazol drench rates of 0.75 or $1.0 \mathrm{mg} /$ pot produced potted plants that were shorter than commercial standards.

Bulb soaks. Regression equations for bulb soak concentrations vs. scape lengths at CSS, days to CSS, scape lengths at senescence, scape dry weights at senescence, and total days to senescence are shown in Fig. 2. All chemical comparisons were highly significant (Table 2). Paclobutrazol bulb soak treatments were effective in limiting scape lengths at CSS and at senescence, whereas ancymidol rates of 2.5 to $10 \mathrm{mg} /$ liter did not affect tulip height (Figs. 2 A and C). Scape dry weights were similarly affected (Fig. 2D). These results are in agreement with previous research (Kincaid and McDaniel, 1979), where 12-hr ancymidol bulb soaks at 2 to 10 $\mathrm{mg} \cdot$ liter $^{-1}$ were ineffective in limiting scape lengths. The equations for days to CSS were essentially linear within the range of chemical rates tested (Fig. 2B). Total days to senescence displayed a significant regression curve for paclobutrazol rates (Fig. 2E). Although days 'to senescence was highest for paclobutrazol bulb soaks, the difference between days to CSS and days to senescence is similar for all treatment rates. Paclobutrazol bulb soaks at 5.0 or $7.5 \mathrm{mg} \cdot \mathrm{liter}^{-1}$ for 1 hr produced commercially acceptable potted tulip heights-that were similar to soil drench treatments. Paclobutrazol bulb soaks at 10 $\mathrm{mg} \cdot 1$ iter $^{-1}$ caused excessively short plants. Neither chemical reduced flower size or affected petal color by either application method.

Paclobutrazol applied either as a soil drench or as a pre-plant bulb soak treatment was shown to be effective in limiting the height of potted tulips. The effectiveness of the paclobutrazol bulb soak when ancymidol remained ineffective at the same concentrations, could be attributed to the ability of paclobutrazol to be absorbed and translocated by the stem tissue of the bulb. Precise quantities of chemical retained by bulbs during the bulb soak treatment were not measured. It is likely that differences in bulb sizes influenced uniformity within the bulb soak treatments, since soil drench treatments resulted in more uniform tulip heights within pots.

The ease of application of paclobutrazol as a pre-plant bulb soak to potted tulips reduces the labor and lack of precision often associated with treatment by soil drenches in commercial practice. The soaking solution will treat a larger quantity of bulbs per volume mixed, and excess solution from treated bulbs may be reused (Lewis and Lewis, 1981). Although there was a significant delay in days to CSS by the higher rates of paclobutrazol bulb soaks, these delays would not be prohibitive for commercial practice.

\section{Literature Cited}

Barrett, J.E. and C.A. Bartuska. 1982. PP333 effects on stem elongation dependent on site of application. HortScience 17:737-738.

De Hertogh, A.A. 1974. Principles for forcing tulips, hyacinths, daffodils, Easter lilies, and Dutch irises. Scientia Hort. 2:313-335.

De Hertogh, A.A. and L.H. Aung. 1968. Technique for identifying stage $\mathrm{G}$ in tulip development. HortScience 3:181-182.

Freeborg, R.P. and W.H. Daniel. 1981. Growth regulation of roadside tall fescue. Proc. Plant Growth Regulat. Working Group 8:95-96.

Gilford, J.M. and A.R. Rees. 1974. The tulip shoot apex. 1. Structure and development. Scientia Hort. 2:1-10.

Kincaid, S. and G.L. McDaniel. 1979. Effects of ancymidol soil drench and time of application of bulb-dips on 'Paul Richter' tulips. HortScience 14:276-277.

Lewis, A.J. and J.S. Lewis. 1980. Response of Lilium longiflorum to ancymidol bulb-dips. Scientia Hort. 13:93-97.

Lewis, A.J. and J.S. Lewis. 1981. Improving ancymidol efficiency for height control of Easter lily. HortScience 16:89-90.

McDaniel, G.L. 1983. Growth retardation activity of paclobutrazol on chrysanthemum. HortScience 18:199-200.

McDaniel, G.L. 1986. Comparison of paclobutrazol, flurprimidol, and tetcyclacis for controlling poinsettia height. HortScience 21:1161-1163.

Menhenett, R. and G.R. Hanks. 1983. Comparison of a new triazole retardant PP333 with ancymidol and other compounds on pot-grown tulips. Plant Growth Regulat. 1:173-181.

Sachs, R.M. and W.P. Hackett. 1972. Chemical inhibition of plant height. HortScience 7:440447.

Shanks, J.B. 1980. Chemical dwarfing of several ornamental greenhouse crops with PP333. Proc. Plant Growth Regulat. Working Group 7:4651.

Shoub, J. and A.A. De Hertogh. 1974. Effects of ancymidol and gibberellins $\mathrm{A}_{3}$ and $\mathrm{A}_{4}+_{7}$ on $T u$ lipa gesneriana L. CV. Paul Richter during development in the greenhouse. Scientia Hort. 2:55-67.

Simmonds, J.A. and B.G. Cumming. 1977. Bulbdip application of growth regulating chemicals for inhibiting stem elongation of 'Enchantment' and 'Harmony' lilies. Scientia Hort. 6:71-81.

Sterrett, J.P. 1985. Paclobutrazol: A promising growth inhibitor for injection into woody plants. J. Amer. Soc. Hort. Sci. 110:4-8. 